\title{
Refuge
}

Canada's Journal on Refugees

Revue canadienne sur les réfugiés

\section{Introduction: Special Issue on Private Sponsorship in Canada}

\section{Johanna Reynolds and Christina Clark-Kazak}

Volume 35, Number 2, 2019

Private Sponsorship in Canada

URI: https://id.erudit.org/iderudit/1064815ar

DOI: https://doi.org/10.7202/1064815ar

See table of contents

Publisher(s)

Centre for Refugee Studies, York University

ISSN

0229-5113 (print)

1920-7336 (digital)

Explore this journal

Cite this document

Reynolds, J. \& Clark-Kazak, C. (2019). Introduction: Special Issue on Private Sponsorship in Canada. Refuge, 35(2), 3-8. https://doi.org/10.7202/1064815ar
Article abstract
Copyright (c) Refuge: Canada’s Journal on Refugees, 2019

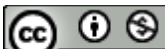

This document is protected by copyright law. Use of the services of Érudit (including reproduction) is subject to its terms and conditions, which can be viewed online.

https://apropos.erudit.org/en/users/policy-on-use/ 


\title{
Introduction: Special Issue on Private Sponsorship in Canada
}

\author{
JOHANNA REYNOLDS and CHRISTINA CLARK-KAZAK
}

\section{Introduction}

The Canadian government, community organizations, sponsorship agreement holders, and ordinary people have invested significant time, energy, and resources in the resettlement of refugees to Canada since the establishment of the private sponsorship program in 1979. Other countries are beginning to adopt and adapt private sponsorship in very different contexts. However, there has been limited research to evaluate the strengths and weaknesses of sponsorship as a resettlement process.

The Private Sponsorship of Refugees (PSR) Program provides Canadian citizens the opportunity to identify and sponsor refugees for resettlement to Canada. For twelve months or more, sponsored refugees receive settlement and financial support from their sponsorship group. A sponsorship group can be formed in various ways: by five or more permanent residents or citizens, also called a Group of Five $\left(G_{5}\right)$, who collectively arrange to sponsor a particular refugee living abroad; or by community sponsors, such as an organization, corporation, or association; and a constituent group, working with a sponsorship agreement holder ( $\mathrm{SAH})$, can also support a refugee or family in their community of settlement. Support during this first year of sponsorship (both through direct service provision and financial support) is provided by the sponsorship group in partnership with service providers. ${ }^{1}$ The
Blended Visa Office-Referred (Bvor) Program, launched in 2013, is a new category of hybrid sponsorship, a cost-sharing initiative between the Canadian government and sponsorship groups, through which refugees are referred for resettlement by UNHCR and approved by Immigration, Refugees and Citizenship Canada (IRCC).

To complement a previous Refuge special issue focusing on the historic establishment of Canada's private sponsorship and a forthcoming edited volume by Shauna Labman and Geoffrey Cameron, this special issue focuses specifically on lessons learned from sponsorship efforts and concrete suggestions for future policy and programming. The articles in this issue make empirical and conceptual contributions to understanding the diversity and context specificity of sponsorship, particularly in relation to the variability of "success," as well as the ways in which Canadian-specific examples can or cannot be "exported" to other countries.

\section{Literature Review: Private Sponsorship in Canada}

While Canada's private sponsorship program has existed for forty years, until recently there was little academic literature evaluating the program and its impacts. Shortly after the large-scale sponsorship and resettlement of Indochinese refugees to Canada in the late 1970s and early 1980s, a few articles described and analyzed the process ${ }^{2}$ and evaluated
(ㄷ) Johanna Reynolds and Christina Clark-Kazak, 2019. This open-access work is licensed under a Creative Commons Attribution-NonCommercial 4.0 International Licence, which permits use, reproduction, and distribution in any medium for non-commercial purposes, provided the original authorship is credited and the original publication in Refuge: Canada's Journal on Refugees is cited.
Cette œuvre en libre accès fait lobjet d'une licence Creative Commons Attribution-NonCommercial 4.o International License, laquelle autorise l'utilisation, la reproduction et la distribution de l'œuvre sur tout support à des fins non commerciales, pourvu que l'auteur ou les auteurs originaux soient mentionnés et que la publication originale dans Refuge: revue canadienne sur les réfugiés soit citée. 
refugees' integration. ${ }^{3}$ In the early 2000 some practitioners published reflections on private sponsorship, ${ }^{4}$ while scholars analyzed resettlement outcomes of sponsored refugees 5 and relationships and partnerships amongst actors involved in sponsorship. ${ }^{6}$ There was also limited literature on the World University Service of Canada's (wusc) Student Refugee Program (SRP). ${ }^{7}$ Despite these important efforts, there was no comprehensive systematic account and evaluation of Canada's private sponsorship system. ${ }^{8}$

To partially redress this gap, a special issue of Refuge 9 focused on the historical establishment of private sponsorship in response to Indochinese refugees. Subsequently Molloy and colleagues published a book ${ }^{10}$ recounting the experiences of Canadian government officials who set up and implemented those early private sponsorship efforts.

In the context of relatively large-scale resettlement of Syrian refugees to Canada through private sponsorship, government assistance, and BVOR channels in 2015-16, and efforts to "export" the Canadian sponsorship model, ${ }^{11}$ new research has emerged. Scholars have focused on motivations and experiences of sponsors, ${ }^{12}$ peer networks, ${ }^{13}$ regional variations, ${ }^{14}$ and new administrative processes and categories of sponsorship. ${ }^{15} \mathrm{~A}$ forthcoming edited volume by Labman and Cameron will use case studies to explore the conceptual and historical basis for sponsorship and prospects for successful "exportation" of the program.

This research has established several important findings about private sponsorship as a resettlement strategy. The discretionary decision-making involved by UNHCR, government actors, and private sponsors naming specific persons to resettle has resulted in some variability in who gets chosen, from what areas, and what resources they have once they arrive in Canada. For example, Turner has critiqued the exclusion of single Syrian men from recent resettlement efforts. ${ }^{16}$ Hyndman, Payne, and Jimenez demonstrate how the prioritization of private sponsorship of Syrians by the Canadian government in 2015-16 caused delays in the resettlement of refugees from other regions. ${ }^{17}$ Sponsorship groups have variable experience in sponsorship, ${ }^{18}$ resulting in uneven support to, and resettlement outcomes of, refugees. ${ }^{19}$ The introduction of a new BVOR sponsorship category also blurs private sponsorship with government assistance. ${ }^{20}$ Relatedly, some critique the privatization of refugee protection. ${ }^{21}$

This special issue complements this literature in three ways. First, while much of the literature has focused on the legal and bureaucratic process of private sponsorship, Kyriakides et al.; Hynie et al.; McKee et al.; Lenard; Good Gingrich and Enns; and Haugen in this issue turn their attention to the micro-level human relationships at the heart of sponsorship. Second, two articles in this issue (Kwadrans and Bond; Hirsch, Hoang, and Vogl) provide a comparative perspective on sponsorship in Canada and other countries. ${ }^{22}$ Third, articles in this special issue attempt to offer practical lessons learned to guide current and future private sponsorship.

\section{Measuring the "Success" of the Canadian Private Sponsorship of Refugees Program}

The articles in the first section consider the variability of "success" in sponsorship programs and perceptions of "success" by sponsored and sponsoring groups. The program has been recognized globally as unique "because it deeply empowered ordinary individuals from any background to take primary responsibility for all aspects of welcoming and integrating the newcomers" (Kwadrans and Bond, this issue). Indeed, the personal efforts and deep commitment of many individuals and refugee sponsorship groups is immeasurable. What motivates civil society to engage in refugee sponsorship? What are some of the complexities of the sponsorsponsored relationship, and how might they be resolved? How is "success" defined and by whom? What markers of "success" are achievable within the first year of arrival, and how can sponsored refugees best achieve them? What conditions make a private sponsorship "successful"? Alternatively, what is viewed as a sponsorship "failure"? The following articles provide strong empirical contributions that frame sponsorship programs in Canada, including student-led initiatives and faith-based groups.

Good Gingrich and Enns aptly explain how markers of refugee success or "integration" are falsely based on an expectation that the sponsored refugee will adapt quickly to the new society, typically defined by a narrow understanding of self-sufficiency, framed as financial independence or an emotional sense of belonging and trust. The authors employ a reflexive analysis that shifts our gaze from the refugee "Other"-the targets of these policies-to the institutional and interpersonal relationships of private refugee sponsorship. They outline the complex nature of these relationships and show how these roles and relationships develop and change. The authors focus on the Mennonite Central Committee (MCC) as their case study, the first agency to set up the private sponsorship of refugees in Canada. They demonstrate how the Mennonite or MMC ethos influenced sponsor-newcomer relationships and associated values and goals in MCC's refugee sponsorships.

According to Kyriakides et al., resettlement success depends in part on pre-arrival communication. Kyriakides et al. demonstrate the importance of regular pre-arrival contact via digital applications such as Facebook, Skype, and Whatsapp for more "successful" and positive resettlement experiences. In their study with groups of privately sponsored Syrian refugees in Ontario, understanding resettlement "needs" was influenced by the level of interpersonal 
trust that had developed between refugees and their sponsors. Pre-arrival exchanges that were conducted via social media have the potential to translate resettlement information into resettlement knowledge assets, what the authors term "third spaces of refugee resettlement," reducing uncertainty by bridging the gap between interpretation and expectation, and the actual conditions encountered in resettlement. The result was to mutually reduce the uncertainty of resettlement. As noted by the authors, another important result of pre-arrival correspondence is that both sponsored and sponsors engaged and corresponded from their respective social roles, thereby also recognizing the needs that corresponded to those roles, be it as parents, spouses, and so on.

However, conditions of variability influence the settlement experience of refugees in Canada. In their mixed-methods study on newly arrived adult Syrian refugees in British Columbia, Ontario, and Quebec, Hynie et al. consider whether early integration benefits observed among governmentassisted refugees (GAR) and PSRS can be attributed to premigration differences, or to the anticipated benefits of private settlement, specifically potential differences in social capital between GARS and PSRs. They apply the holistic integration model, which moves the responsibility for success (or failure) of integration purely from the individual level, to also include conditions in the dominant host society and broader socio-political contexts of integration (e.g., colonial, racist, and xenophobic policies). The authors demonstrate that a host of pre-migration conditions affect the integration pathway, including length of time in transit and associated physical and psychological hardships, previous knowledge of English/French, having relatives in Canada, and the importance of local contexts in which they settle. Importantly, the authors show that PSRs are not a homogenous group and that comparing settlement outcomes of PSRS with other groups such as GARs is ineffective, given the variability within and between the categories.

The importance of place in settlement outcomes is also clearly demonstrated in Haugen's article, which discusses the important role that smaller cities or rural communities play in hosting privately sponsored refugees. Despite inadequate infrastructure and settlement challenges in smaller communities (e.g., lack of newcomer services, lack of public transportation, limited access to higher education, and religious and racial discrimination), rural communities can also offer benefits to refugee families who decide to remain there, including affordable housing and strong social supports. The author's findings from rural communities in Alberta, Saskatchewan, Ontario, and Nova Scotia emphasize the uniqueness of place while at the same time contribute to knowledge about the process of integration and refugee resettlement experiences outside urban centres.
Lenard draws attention to the structural conditions that make independence within one year difficult to achieve. The infamous "month 13 " requires that refugees become independent with a year of their arrival, and sponsors are tasked with supporting their pathway to independence. And yet multiple conditions and variables result in refugees not being prepared to be on their own by the time their sponsorship ends. Lenard explains that there is also a common misunderstanding of what constitutes independence, or what skills are needed for newcomers to become independent, including tensions between sponsors and sponsored around financial budgeting. For example, a common misconception is that financial self-sufficiency is synonymous with integration. Lenard shows that there is need for a deeper and more nuanced understanding of what "success" at month 13 looks like and that independence and integration into Canadian society is gradual: "The failure to attain it by month 13 means neither that the newcomers have failed, nor that the sponsorship has failed."

The article by McKee et al. focuses on the World University Services of Canada (wusc) Student Refugee Program. This youth-to-youth sponsorship model is an effective approach to integrate young refugees into their receiving community. Youth volunteers, they argue, can play an important role in supporting integration for newcomers to Canada. More than 130 refugee students are resettled to Canadian postsecondary institutions each year, through more than ninety campus-based wUsc local committees. The authors argue that resettling refugee youth to Canadian post-secondary institutions reduces many barriers to integration faced by other refugee youth, such as providing access to education, language training, and employment opportunities. Their results show that local committees were instrumental in providing refugee students with job opportunities both on and off campus. Furthermore, interviewed participants also indicated feeling "at home" and attributed this feeling to the support of the local committee and the broader community, even in cases where their ethnic community was largely absent. An important lesson from the SRP is that "youth are uniquely positioned as innovative leaders capable of mobilizing their peers and community on global issues." Engaging students in refugee sponsorship by raising awareness about global migration can have ripple effects both on campus and in the broader community.

These articles collectively demonstrate that pre-arrival conditions, social and structural barriers, policies, and institutional supports all need to be carefully considered when assessing what constitutes the "successful" integration of newcomers to Canada. 


\section{Private Sponsorship in a Global Context}

The second section highlights examples of private sponsorship programs in other countries that seek community-based solutions to fill the resettlement gap. Community sponsorship programs are unique in that they empower ordinary citizens to welcome and integrate refugee newcomers into their communities. They are viewed as a complementary model to state-led resettlement commitments. How does such a program function when there is no national framework, as in the United States? Or when the state uses community-based solutions in lieu of their own national commitments, which result in downloaded responsibility, as in Australia?

Bond and Kwadrans provide a comparative analysis of the legal and administrative frameworks that have underpinned sponsorship programs in Canada, the United Kingdom, New Zealand, and Argentina. They also briefly examine the introduction of co-sponsorship in the United States, a country without any formal national program. What policy structures are required to operationalize community sponsorship programs? The authors highlight a historic overview of the Canadian model, focusing on the original legislative changes that created the foundations for the world's largest community sponsorship program. As they further explain, the Canadian model offered a unique referral mechanism that permitted sponsors to identify refugees they wished to resettle and was enabled by an explicit provision in the 1976 Immigration Act. This model underscores the very minimal legislative framework necessary to facilitate introduction of this radically different approach to refugee resettlement. The United Kingdom and New Zealand, on the other hand, each introduced community sponsorship into pre-existing and well-established refugee resettlement infrastructure. Alternatively Argentina-a newer resettlement country-created a resettlement program delivered exclusively through a sponsorship model. The final case study, the United States, is a large resettlement country that does not have a national community sponsorship program. Nevertheless, a number of American civil society organizations have recognized the potential of sponsorship and built their own mini infrastructure within the country's broader overall resettlement scheme. The authors show that sponsorship models are not "one size fits all," encouraging countries to consider new sponsorship programs without undertaking wide-scale legislative reform.

Hirsch, Hoang, and Vogl examine Australia's current Community Support Program (CSP), which began in late 2017 , as a cautionary tale: a sponsorship program that reduces government accountability and financial commitment to humanitarian resettlement programming. The authors also demonstrate that the eligibility criteria for CSP shows a preference for "job ready," "economically self-sufficient" refugees between the ages of eighteen and fifty, with "functional English," an overall higher integration capacity, and from particular countries of origin. This "cherry picking" of refugees undermines the humanitarian nature of this program and discriminates on the basis of gender, age, and other criteria. The authors provide an important discussion on whether this program can preserve its humanitarian focus as a durable solution for refugees or whether economic independence and other criteria in fact support an economic model of self-sufficiency.

\section{The Future of Private Sponsorship?}

The Global Compact on Refugees calls upon states "to establish private or community sponsorship programs that are additional to regular resettlement" in order to provide timely access to durable solutions to refugees." ${ }^{23}$ Canada's private sponsorship program has gained global attention as a leader in refugee resettlement. ${ }^{24}$ In 2019 Canada will resettle four times more privately sponsored refugees than in $2015 .{ }^{25} \mathrm{It}$ is thus imperative that we pay close attention to the evaluation of Canada's private sponsorship system and the lessons learned provided in new and emerging research to guide future private sponsorship.

\section{Notes}

1 For more on settlement-sponsor collaboration, see Allies for Refugee Integration (ARI), Promoting Settlement-Sponsor Collaboration: Best Practices Report-April 2019, http://ocasi .org/sites/default/files/promoting-settlement-sponsorcollaboration-best-practices-report.pdf.

2 Michael C. Lanphier, "Refugee Resettlement: Models in Action," International Migration Review 17, no. 1 (1983): 4-33; Doreen Marie Indra, "The Spirit of the Gift and the Politics of Resettlement: The Canadian Private Sponsorship of South East Asians," in The International Refugee Crisis, ed. Vaughan Robinson, 229-54 (London: Palgrave Macmillan, 1993).

3 Gertrud Neuwirth and Lynn Clark, "Indochinese Refugees in Canada: Sponsorship and Adjustment," International Migration Review 15, no. 1-2 (1981): 131-40; YuenFong Woon, "Indochinese Refugee Sponsorship: The Case of Victoria, 1979-1980," Canadian Ethnic Studies 16, no. 1 (1984): 57.

4 Thomas R. Denton, "Understanding Private Refugee Sponsorship in Manitoba," Journal of International Migration and Integration/Revue de lintégration et de la migration internationale 4, no. 2 (2003): 257-72; Barbara Treviranus and Michael Casasola, "Canada's Private Sponsorship of Refugees Program: A Practitioner's Perspective of Its Past and Future," International Migration \& Integration 4 (2003): 177.

5 Morton Beiser, "Sponsorship and Resettlement Success," Journal of International Migration and Integration/Revue de 
l'intégration et de la migration internationale 4, no. 2 (2003): 203-15; Soojin Yu, Estelle Ouellet, and Angelyn Warmington, "Refugee Integration in Canada: A Survey of Empirical Evidence and Existing Services," Refuge 24, no. 2 (2007): 17-34; Nicole Ives, "More Than a 'Good Back': Looking for Integration in Refugee Resettlement," Refuge 24, no. 2 (2007): 54-63.

6 Michael Lanphier, "Sponsorship: Organizational, Sponsor, and Refugee Perspectives," Journal of International Migration and Integration 4, no. 2 (2003): 237-56; Laura Simich, "Reinforcing Refugee Resettlement: An Introduction to Private Sponsorship and Partnerships," Journal of International Migration and Integration/Revue de l'intégration et de la migration internationale 4, no. 2 (2003): 153-6; Nicole Ives and Jill Witmer Sinha, "The Religious Congregation as Partner in Refugee Resettlement," Settlement of Newcomers to Canada 12, no. 1 (2010): 210-17.

7 Glen Peterson, "Education Changes the World': The World University Service of Canada's Student Refugee Program," Refuge 27, no. 2 (2012): 111-21; Robyn Plasterer, "Investigating Integration: The Geographies of the wusc Student Refugee Program at the University of British Columbia," Refuge 27, no. 1 (2010): 59-74.

8 A good summary of the program can be found in Jennifer Hyndman, William Payne, and Shauna Jimenez, "The State of Refugee Private Sponsorship in Canada," RRN/CRs Policy Brief submitted to the government of Canada, 2 December 2016,https://refugeeresearch.net/rrn_node/private-refugeesponsorship-in-canada/; and Jennifer Hyndman, William Payne, and Shauna Jimenez, "Private Refugee Sponsorship in Canada," Forced Migration Review; Oxford 54 (February 2017): 56-9.

9 Refuge 32, no. 2, https://refuge.journals.yorku.ca/index.php/ refuge/issue/view/2311.

10 Michael J. Molloy, Peter Duschinsky, Kurt F. Jensen, and Robert J. Shalka, Running on Empty: Canada and the Indochinese Refugees, 1975-1980 (Montreal and Kingston: McGill-Queen's University Press, 2017).

11 Government of Canada, "Global Refugee Sponsorship Initiative," last modified 18 July 2018, https://www.canada.ca/ en/immigration-refugees-citizenship/corporate/mandate/ corporate-initiatives/global-refugee-sponsorship-initiative .html.

12 Patti Tamara Lenard, "Resettling Refugees: Is Private Sponsorship a Just Way Forward?" Journal of Global Ethics 12, no. 3 (2016): 300-10; Audrey Macklin, Kathryn Barber, Luin Goldring, Jennifer Hyndman, Anna Korteweg, Shauna Labman, and Jona Zyfi, "A Preliminary Investigation into Private Refugee Sponsors," Canadian Ethnic Studies 50, no. 2 (2018): 35-57, https://doi.org/10.1353/ces.2018.0014; Shannon Tito and Sharolyn Cochand, "The Story of a Small Canadian Congregation Sponsoring a Refugee Family," Forced Migration Review 54 (2017): 60; Anna Hutchinson, "'Welcome to Canada': Hospitality, Inclusion and Diversity in Private Refugee Sponsorship," UCL Migration Research Unit Working Papers No. 2018/2.

13 Alexander Norfolk, "Establishing a Stronger Peer Resource Network for the Private Sponsorship of Refugees Program at the Inter-Cultural Association of Greater Victoria" (MA thesis, University of Victoria, 2017).

14 Sandeep Kumar Agrawal, "Canadian Refugee Sponsorship Programs: Experience of Syrian Refugees in Alberta, Canada," Journal of International Migration and Integration 19, no. 4 (2018): 1-22.

15 Shauna Labman and Madison Pearlman, "Blending, Bargaining, and Burden-Sharing: Canada's Resettlement Programs," Journal of International Migration and Integration 19, no. 2 (2018): 439-49, https://doi.org/10.1007/ s12134-018-0555-3.

16 Lewis Turner, "Who Will Resettle Single Syrian Men?" Forced Migration Review 54 (2017): 29-31.

17 Hyndman, Payne, and Jimenez, "Private Refugee Sponsorship in Canada," 56.

18 Tito and Cochand, "Story of a Small Canadian Congregation," 6o; Julie Drolet, Richard Enns, Linda Kreitzer, Janki Shankar, and Anne-Marie McLaughlin, "Supporting the Resettlement of a Syrian Family in Canada: The Social Work Resettlement Practice Experience of Social Justice Matters," International Social Work 61, no. 5 (2018): 627-33.

19 Jill Hanley, Adnan Al Mhamied, Janet Cleveland, Oula Hajjar, Ghayda Hassan, Nicole Ives, Rim Khyar, and Michaela Hynie, "The Social Networks, Social Support and Social Capital of Syrian Refugees Privately Sponsored to Settle in Montreal: Indications for Employment and Housing during Their Early Experiences of Integration," Canadian Ethnic Studies 50, no. 2 (2018): 123-48; Navjot K. Lamba and Harvey Krahn, "Social Capital and Refugee Resettlement: The Social Networks of Refugees in Canada," Journal of International Migration and Integration/Revue de l'intégration et de la migration internationale 4, no. 3 (2003): 335-60; Morton Beiser, "Sponsorship and Resettlement Success," Journal of International Migration and Integration/Revue de l'intégration et de la migration internationale 4, no. 2 (2003): 203-15; Lisa Kaida, Feng Hou, and Max Stick, "The Long-Term Economic Integration of Resettled Refugees in Canada: A Comparison of Privately Sponsored Refugees and Government-Assisted Refugees," Journal of Ethnic and Migration Studies 45, no. 12 (2019): 1-22; Michaela Hynie, "Canada's Syrian Refugee Program, Intergroup Relationships and Identities," Canadian Ethnic Studies 50, no. 2 (2018): 1-12.

20 Anthea Vogl and A. Hirsch, "Community Members Should Be Able to Sponsor Refugees for the Right Reasons, Not to Save the Government Money," Conversation, 7 March 2019; Shauna Labman and Madison Pearlman, "Blending, Bargaining, and Burden-Sharing: Canada's Resettlement Programs," Journal of International Migration and Integration 19, no. 2 (2018): 439-49; Shauna Labman, "Private Sponsorship: Complementary or Conflicting Interests?" Refuge 
32, no. 2 (2016): 67-80; Lenard, "Resettling Refugees; Lori Wilkinson and Joseph Garcea, The Economic Integration of Refugees in Canada: A Mixed Record? (Washington, DC: Migration Policy Institute, 2017); Ray Silvius, "Neo-Liberalization, Devolution, and Refugee Well-Being: A Case Study in Winnipeg, Manitoba," Canadian Ethnic Studies 48, no. 3 (2016): 27-44; Hyndman, Payne, and Jimenez, "Private Refugee Sponsorship in Canada," 56.

21 Genevieve Ritchie, "Civil Society, the State, and Private Sponsorship: The Political Economy of Refugee Resettlement," International Journal of Lifelong Education 37, no. 6 (2018): 663-75.

22 See also Samantha Arnold and Emma Quinn, "Resettlement of Refugees and Private Sponsorship in Ireland," Economic and Social Research Institute Research Series (2016); Shahana Bhaduri, "Exploring Private Refugee Sponsorship Option(s) for the United States" (PhD diss., Harvard University, 2018).

23 United Nations High Commissioner for Refugees, "Global Compact on Refugees," 18, https://www.unhcr.org/gcr/ GCR_English.pdf.
24 United Nations High Commissioner for Refugees, "Amid Record High Global Displacement, un Refugee Agency Calls for International Solidarity, Welcomes Canadian Generosity towards Refugees," https:/www.unhcr.ca/news/ amid-record-high-global-displacement-unhcr-welcomescanadian-generosity-towards-refugees/.

25 Government of Canada, "Canada Welcomes More Privately Sponsored Refugees in 2019," https://www.canada.ca/en/ immigration-refugees-citizenship/corporate/mandate/ policies-operational-instructions-agreements/timelyprotection-privately-sponsored-refugees.html.

Johanna Reynolds is research coordinator for a SSHRC-funded project on private refugee sponsorship in Canada. She may be contacted at jreynol@yorku.ca.

Christina Clark-Kazak is associate professor, Graduate School of Public and International Affairs, University of Ottawa. She may be contacted at cclarkka@uottawa.ca. 